\title{
RISK ASSESSMENT OF BOOT HYDROPOWER PROJECTS IN NEPAL USING FUZZY LOGIC APPROACH
}

\author{
Er. Pramesh Tripathi ${ }^{1}$, Er. Santosh Kumar Shrestha ${ }^{2}$ \\ ${ }^{1} \mathrm{MSc}$ Construction Management, IOE, Pulchowk Campus \\ Email Address: p_pramesh@yahoo.com \\ ${ }^{2}$ Lecturer, Department of Civil Engineering, IOE, Pulchowk Campus \\ Email Address: skshrestha1969@gmail.com
}

\begin{abstract}
Many Hydropower Projects in Nepal are carried out with insufficient risk assessment because of which time over run or variations are predominant. Many projects are stuck in preconstruction phase and others in construction phase.

In this study all possible risks associated with the BOOT Hydropower Project in Nepal were identified and evaluated. Fuzzy rating tool has been used to quantify the risk associated with the BOOT Hydropower Projects in Nepal. It provides a flexible and easily understood way to analyze the project risks.

The relative importance (impact) of risk factors was determined from the survey results. A set of questionnaire was prepared for the survey. The survey was conducted with the experts that have experience in BOOT hydropower projects. From the survey, among the type of risks, Grid Connection / Power Evacuation, Political risk and Geological risk were found to be predominant risk respectively in BOOT hydropower projects in Nepal. The risk assessment method enabled a Risk Index (R) value to be calculated, establishing a 4-grade evaluation system: low risk having $\mathrm{R}$ values between 1.17 and 1.69; medium risk, between 1.69 and 2.08; high risk, between 2.08 and 2.47; extreme risk, between 2.47 and 2.78.

Applicability of the methodology was tested on a real case hydropower project namely Middle Modi Hydroelectric Project (15.1 MW) which is in construction phase on Modi River in Western Region in Nepal and Madhya Bhotekosi Jalavidyut Company Ltd. (102 MW) which is also in construction phase on Bhotekoshi River in Central Region in Nepal.

The risk analysis method will give investors a more rational basis on which to make decisions and it can prevent cost and schedule overruns. An overall risk index can be used as early indicators of project problems or potential difficulties. Evaluators can keep track to evaluate the current risk level with the progress of investments.
\end{abstract}

Key words: Risk, BOOT Hydropower Project, Fuzzy Logic

\section{Introduction}

Risk Management can be considered as one of the most creative task of the project management. Risk is inherent in all construction work no matter what the size of a project or the scope of the work. Size can be one of the major causes of risk, so can changes in political or economic planning. Other factors carrying risk with them include the complexity of the project, location, speed of construction and familiarity with the type of work. The evidence of many projects reveals that these risks are not being adequately dealt with.

Hydropower plants are becoming nowadays an attractive alternative for both government and investors. The government of Nepal is currently encouraging private investors to invest in hydro electricity generation, through concession agreements and different type of contracts while guaranteeing the purchase of their output.

Nepal has an enormous potential for generating electric energy from its water resources. Due to the availability of large number of snow fed and monsoon fed rivers in Nepal, there is a large potential for hydropower development. Nepal's immense hydropower potential needs to exploit in broadening the 
market that is developing in domestic and regional areas. Yet, less than $2 \%$ of this capacity has been developed.

Due to Nepal's strategic location between two giant economics China and India, Nepal has a competitive edge in producing and selling hydroelectricity. Power shortages in the region continue to constrain economic development. The domestic as well as regional market for the electricity is vast and rapidly growing. Being a mountainous country, consisting mainly of a large portion of Himalayas with huge rise and fall providing excellent head in short span, there are tremendous resources for the generation electricity.

Hydropower development in Nepal is happening at a very low pace due to various challenges/risks such as lack of investment, political instability, human resource constraints and lack of suitable plans and policies. Despite the challenges, the government has been trying its best to formulate effective plans and policies to attract domestic as well as foreign investments in the hydropower sector. All small, medium and mega hydropower projects involve various type of risk which should be studied and managed right from the beginning of the project.

\section{Methodology}

The sixteen classes of risk factors were determined based on the expert interviews (Interview was done with Er. Arun Rajauria, Deputy General Manager, Hydroelectricity Investment and Development Company Ltd. \& Er. Sagar Siwakoti, Engineer, Hydroelectricity Investment and Development Company Ltd.), field studies and literature review from various journals published in the websites. The risk factors and their evaluation criteria are listed in Table 1. The risk factors are: Institutional risk (change in policies, laws and regulations, Political risk (problems with permit and licenses, human resource, withdrawal of tax facilities by government, civil disturbances, banda), Geological risks (sub surface investigation ), Grid connection / Power evacuation (construction of transmission lines and connection in the national grid), Revenue risks (income through the plant), Construction risk (labor strikes, work methodology, inclement weather, quality problem, poor site safety, poor productivity, losses and delay due to improper means and method of construction), Natural risk (earthquake, losses due to fire and accident, GLOF, landslide, flood, storm), Design risk (specification, change in scope, new technology, design change, losses or delay due to differing site conditions, poor detailing in drawings), Logistic risk (loss or delay due to damaged or late material, loss or delay due to resources availability, access to site, availability of equipment, delay in addressing or solving problem), Financial risk (foreign exchange risk, sovereign risk (country risk), interest rate risk, revenue risk, payment risk), Environmental risk (air pollution, noise pollution, changes in river flow, erosion and creation on the bank of reservoir, water borne diseases, effects on wildlife system, effects on fish and aquatic beings, forest loss), Organizational risk (capability of owner's project group, contractor's failure, vendor's failure, consultant's failure), Social risk (resettlement of local people, migration and change in livelihood of local people, demand of funds by local people, demand of various infrastructures by local people), Land use (right to use of the land for the construction of hydropower scheme) Operational risk (generation, transmission, distribution, outage, electromechanical equipment, hydro-mechanical equipment, Operation/Maintenance manual with trainings) and Health risk (high altitude, availability of health services, emergency rescue).

In order to determine the relative importance (impact) of the risk factors, a survey was conducted with the experts from the banks and companies that have experience in the construction of BOOT hydropower schemes. The participants were asked to grade the importance of the risk factors regarding their importance and seriousness of concern. They graded the risk factors using a scale between 1-4, where 1 represents "low", 2 represents "medium", 3 represents "high", and 4 represents "extreme". 
Table 1 Evaluation Criteria of Risk Factors

\begin{tabular}{|c|c|c|c|c|c|}
\hline S.No. & Risk factor & Score 1 & Score 2 & Score 3 & Score 4 \\
\hline 1 & $\begin{array}{l}\text { Institutional } \\
\text { Risks }\end{array}$ & $\begin{array}{l}\text { No change in policies, } \\
\text { law and regulation }\end{array}$ & $\begin{array}{l}\text { Revision in } \\
\text { policies, law } \\
\text { and regulation } \\
\text { once in a } \\
\text { decade }\end{array}$ & $\begin{array}{l}\text { Often change } \\
\text { in policies, law } \\
\text { and regulation }\end{array}$ & $\begin{array}{c}\text { Frequent } \\
\text { change in } \\
\text { policies, law } \\
\text { and } \\
\text { regulation }\end{array}$ \\
\hline 2 & $\begin{array}{l}\text { Political } \\
\text { Risks }\end{array}$ & $\begin{array}{l}\text { Political risk of } \\
\text { country is low }\end{array}$ & $\begin{array}{l}\text { Political risk } \\
\text { of country is } \\
\text { medium }\end{array}$ & $\begin{array}{c}\text { Political risk } \\
\text { of country is } \\
\text { high }\end{array}$ & $\begin{array}{c}\text { Political risk } \\
\text { of country is } \\
\text { very high }\end{array}$ \\
\hline 3 & $\begin{array}{l}\text { Geological } \\
\text { Risks }\end{array}$ & $\begin{array}{l}\text { Rock mass } \\
\text { quality is good- } \\
\text { very good: RQ } \\
=60 \%-100 \%\end{array}$ & $\begin{array}{c}\text { Rock mass } \\
\text { quality is fair: } \\
\text { RQ }=40 \%- \\
59 \%\end{array}$ & $\begin{array}{c}\text { Rock mass } \\
\text { quality is very } \\
\text { poor- poor } \\
\mathrm{RQ}=0 \%-39 \%\end{array}$ & $\begin{array}{c}\text { Soil with } \\
\text { high ground } \\
\text { water level }\end{array}$ \\
\hline 4 & $\begin{array}{c}\text { Grid } \\
\text { Connection }\end{array}$ & $\begin{array}{l}\text { Close to power } \\
\text { system }\end{array}$ & $\begin{array}{l}\text { Near to power } \\
\text { system }\end{array}$ & $\begin{array}{l}\text { Far to power } \\
\text { system }\end{array}$ & $\begin{array}{c}\text { Connection } \\
\text { to the power } \\
\text { system has } \\
\text { some } \\
\text { limitations }\end{array}$ \\
\hline 5 & $\begin{array}{l}\text { Revenue } \\
\text { Risk }\end{array}$ & $\begin{array}{l}\text { Design discharge is } \\
\text { high reliable }\end{array}$ & $\begin{array}{l}\text { Design } \\
\text { discharge is } \\
\text { medium } \\
\text { reliable }\end{array}$ & $\begin{array}{c}\text { Design } \\
\text { discharge is } \\
\text { low reliable }\end{array}$ & $\begin{array}{c}\text { Design } \\
\text { discharge is } \\
\text { unreliable }\end{array}$ \\
\hline 6 & $\begin{array}{l}\text { Construction } \\
\text { Risks }\end{array}$ & $\begin{array}{l}\text { Contractor is } \\
\text { highly qualified } \\
\text { in his job }\end{array}$ & $\begin{array}{l}\text { Use of new } \\
\text { construction } \\
\text { technology } \\
\text { not practiced } \\
\text { by the } \\
\text { contractor }\end{array}$ & $\begin{array}{l}\text { Contractor has } \\
\text { unskilled } \\
\text { manpower and } \\
\text { old equipment }\end{array}$ & $\begin{array}{l}\text { Contractor } \\
\text { has never } \\
\text { worked in } \\
\text { any hydro } \\
\text { projects }\end{array}$ \\
\hline 7 & Land use & $\begin{array}{l}\text { Property of the } \\
\text { Government }\end{array}$ & $\begin{array}{c}\text { It is the Forest } \\
\text { area }\end{array}$ & $\begin{array}{c}\text { Private } \\
\text { property: } \\
\text { Agricultural } \\
\text { land }\end{array}$ & $\begin{array}{l}\text { Private } \\
\text { property: } \\
\text { Residential } \\
\text { area }\end{array}$ \\
\hline 8 & $\begin{array}{c}\text { Natural } \\
\text { Risks }\end{array}$ & $\begin{array}{l}\text { Site geology is } \\
\text { is very good }\end{array}$ & $\begin{array}{c}\text { Landscape of } \\
\text { the } \\
\text { surrounding } \\
\text { area is } \\
\text { moderately }\end{array}$ & $\begin{array}{l}\text { Project lies in } \\
\text { main } \\
\text { Himalayan } \\
\text { thrust }\end{array}$ & $\begin{array}{c}\text { High } \\
\text { probability of } \\
\text { GLOF \& } \\
\text { Landslide }\end{array}$ \\
\hline
\end{tabular}




\begin{tabular}{|c|c|c|c|c|c|}
\hline & & & slope & & \\
\hline 9 & Social risk & $\begin{array}{c}\text { Project has } \\
\text { detailed Social } \\
\text { Impact Report }\end{array}$ & $\begin{array}{c}\text { Project has } \\
\text { Social Impact } \\
\text { Report }\end{array}$ & $\begin{array}{c}\text { Project has no } \\
\text { Social Impact } \\
\text { Report }\end{array}$ & $\begin{array}{l}\text { Local } \\
\text { community } \\
\text { suffers the } \\
\text { most }\end{array}$ \\
\hline 10 & $\begin{array}{c}\text { Design } \\
\text { Risks }\end{array}$ & Design is done by experts & $\begin{array}{c}\text { Designs is } \\
\text { done by } \\
\text { inexperienced } \\
\text { ones }\end{array}$ & $\begin{array}{l}\text { Designs does } \\
\text { not meet the } \\
\text { project site } \\
\text { environment }\end{array}$ & $\begin{array}{l}\text { Designs is } \\
\text { done with } \\
\text { less site } \\
\text { investigation }\end{array}$ \\
\hline 11 & $\begin{array}{c}\text { Environment } \\
\text { Risk }\end{array}$ & $\begin{array}{c}\text { Project has } \\
\text { detailed } \\
\text { Environmental } \\
\text { Impact Report }\end{array}$ & $\begin{array}{c}\text { Project has } \\
\text { Environmenta } \\
1 \text { Impact } \\
\text { Report }\end{array}$ & $\begin{array}{l}\text { Project has no } \\
\text { Environmental } \\
\text { Impact Report }\end{array}$ & $\begin{array}{c}\text { Project is in } \\
\text { an ecological } \\
\text { sensitive } \\
\text { area. }\end{array}$ \\
\hline 12 & $\begin{array}{l}\text { Logistic } \\
\text { Risks }\end{array}$ & $\begin{array}{l}\text { Have enough } \\
\text { equipment's\& resources } \\
\text { with proper planning \& } \\
\text { methods }\end{array}$ & $\begin{array}{c}\text { Have } \\
\text { moderate } \\
\text { experience in } \\
\text { construction } \\
\text { works }\end{array}$ & $\begin{array}{c}\text { Poor } \\
\text { communicatio } \\
\mathrm{n} \& \text { delay in } \\
\text { addressing } \\
\text { problems }\end{array}$ & $\begin{array}{c}\text { Have old } \\
\text { equipment's } \\
\text { \& resources } \\
\text { with poor } \\
\text { planning \& } \\
\text { methods }\end{array}$ \\
\hline 13 & $\begin{array}{c}\text { Financial } \\
\text { Risks }\end{array}$ & $\begin{array}{c}\text { Economic } \\
\text { performance of } \\
\text { owner is very } \\
\text { high }\end{array}$ & $\begin{array}{c}\text { Economic } \\
\text { performance } \\
\text { of owner is } \\
\text { high }\end{array}$ & $\begin{array}{l}\text { Economic } \\
\text { performance } \\
\text { of owner is } \\
\text { medium }\end{array}$ & $\begin{array}{c}\text { Economic } \\
\text { performance } \\
\text { of owner is } \\
\text { low }\end{array}$ \\
\hline 14 & $\begin{array}{l}\text { Organization } \\
\text { al Risks }\end{array}$ & $\begin{array}{c}\text { Organization have } \\
\text { experienced human } \\
\text { resource \& management }\end{array}$ & $\begin{array}{l}\text { Organization } \\
\text { have well } \\
\text { managed } \\
\text { system }\end{array}$ & $\begin{array}{l}\text { Organization } \\
\text { have un } \\
\text { managed } \\
\text { system }\end{array}$ & $\begin{array}{c}\text { Organization } \\
\text { have poor } \\
\text { human } \\
\text { resource \& } \\
\text { management }\end{array}$ \\
\hline 15 & $\begin{array}{c}\text { Operational } \\
\text { Risks }\end{array}$ & $\begin{array}{l}\text { Very easy to } \\
\text { operate \& } \\
\text { maintain }\end{array}$ & $\begin{array}{c}\text { Easy to } \\
\text { operate \& } \\
\text { maintain }\end{array}$ & $\begin{array}{l}\text { Difficult to } \\
\text { operate \& } \\
\text { maintain }\end{array}$ & $\begin{array}{l}\text { Frequent } \\
\text { breakdown \& } \\
\text { difficult to } \\
\text { maintain }\end{array}$ \\
\hline 16 & Health risk & $\begin{array}{l}\text { Site is located in } 500 \mathrm{~m} \text { to } \\
1500 \mathrm{~m} \text { altitude }\end{array}$ & $\begin{array}{c}\text { Site is located } \\
\text { in } 1500 \mathrm{~m} \text { to } \\
2500 \mathrm{~m} \\
\text { altitude }\end{array}$ & $\begin{array}{c}\text { Site is located } \\
\text { in } 2500 \mathrm{~m} \text { to } \\
3500 \mathrm{~m}\end{array}$ & $\begin{array}{c}\text { Site is } \\
\text { located above } \\
3500 \mathrm{~m}\end{array}$ \\
\hline
\end{tabular}


For each 16 parameters, a real case of a BOOT hydropower project is evaluated and an input matrix of order $1 \times 4$ is developed, each column corresponding scores $1-4$. For example, if the score for a parameter is 2 and the input matrix $(I)$ for the parameter is:

$\mathrm{I}=\left[\begin{array}{llll}0 & 1 & 0 & 0\end{array}\right]$

Each parameter has a membership grading matrix. The membership grading matrix suspends the Boolean logic in the input matrices and reverberates the fuzziness in the methodology. The membership grading matrices is developed considering the degree of error a scoring observer may cause due to subjectivity and bias in the assessment process. The following membership grading matrix M13 for Construction risk is an example:

$$
\mathrm{M}_{13}=\begin{aligned}
& 1 \\
& 3 \\
& 4
\end{aligned}\left[\begin{array}{llll}
1 & 0.2 & 0 & 0 \\
0.2 & 1 & 0.2 & 0 \\
0 & 0.2 & 1 & 0.2 \\
0 & 0 & 0.4 & 1
\end{array}\right]
$$

Eq. (2) shows the fuzzy grading matrix $(F G)$ for Construction risk.

Each row in the matrix corresponds to attribute scores from 1 to 4 respectively. If Boolean logic was used, the matrix would be identity matrix. However, a $100 \%$ score for a specific attribute may take some parts from lower and upper attributes to some degrees. For example; when Construction risk parameter is scored as 3 for XYZ Project, it is scored as $100 \%$ as 3,20\% as 2 and $20 \%$ as 4 . This may be considered as an error modification. The membership degrees were determined by the expert group.

The fuzzy assessment matrix $(F A)$ was obtained by multiplying input matrices $(I)$ with fuzzy grading matrix $(F G)$ of the parameter,

$$
F A_{j}=I_{j} \times F_{j} \quad(j=1 \text { to } 16)
$$

Where, $\mathrm{j}$ is the row number of the fuzzy assessment matrices. The membership degree matrix $(M D)$ was obtained by multiplying weight of parameters $(w)$ with fuzzy assessment matrix $(F A)$ and summing the columns resulting in a one row matrix;

$\mathrm{MD}=\mathrm{W} \times \mathrm{FA}$

The weighted average method is used in the procedure. The maximum truth (height) of each output fuzzy set is used to calculate the weighted average of maximum truth. This method gives the average, weighted by their degree of truth, of the support values at which all the membership functions that apply reach their maximum value and formulation of Risk Index $(R)$ was given as

$$
R=\frac{1 x A_{12}+2 x A_{23}+3 x A_{34}}{A_{T}}
$$

Whereas, the area under the curve between the attributes $i$ and $j$ is named as $A_{i j}$ with: $i=1,2 \& 3$ and $j$ $=2,3 \& 4$. The total area under the curve is $\mathrm{A}_{\mathrm{T}}$. This enabled a Risk Index $(R)$ value to be calculated, establishing a 4-grade evaluation system: Low risk having $\mathrm{R}$ values between 1.17 and 1.69; medium risk, between 1.69 and 2.08; high risk, between 2.08 and 2.47; extreme risk, between 2.47 and 2.78. The risk scale index represents the minimum and maximum values calculated by Eq. (5). 
Table 2 Answers of each of the 20 experts for the importance of the risk factors. The survey was done based on a qualitative basis: Low $=1$, Medium $=2$, High $=3$ and $E x t r e m e=4$.

\begin{tabular}{|c|c|c|c|c|c|c|c|c|c|c|c|c|c|c|c|c|c|c|c|c|c|c|}
\hline Parameters & 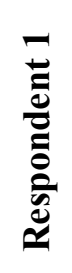 &  & 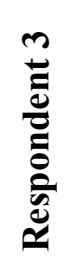 & 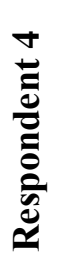 & 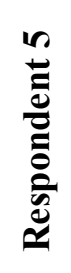 & 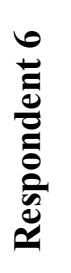 & 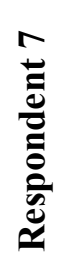 & 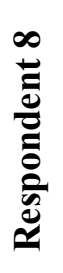 & 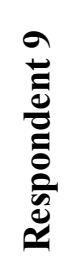 & 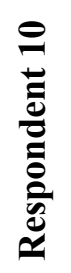 & 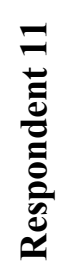 & 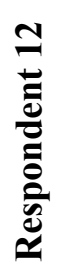 & 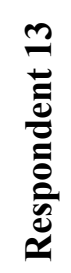 & 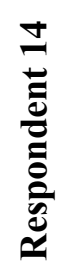 & 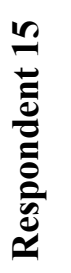 & 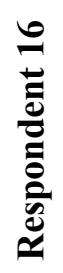 & 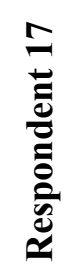 & 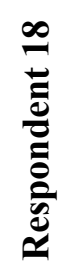 & 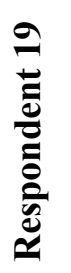 & 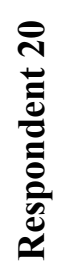 & 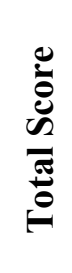 & 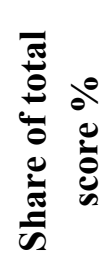 \\
\hline a. Institutional Risks & 3 & 3 & 2 & 3 & 3 & 2 & 2 & 2 & 2 & 2 & 4 & 1 & 1 & 2 & 3 & 2 & 1 & 1 & 2 & 2 & 43 & 0.055 \\
\hline b. Political Risks & 4 & 3 & 4 & 3 & 4 & 3 & 3 & 3 & 4 & 4 & 4 & 3 & 3 & 3 & 3 & 3 & 4 & 3 & 3 & 4 & 68 & 0.088 \\
\hline c. Geological Risks & 3 & 2 & 2 & 2 & 2 & 2 & 3 & 3 & 2 & 3 & 2 & 2 & 4 & 3 & 4 & 3 & 3 & 2 & 2 & 3 & 52 & 0.067 \\
\hline d. Grid connection / Power evacuation & 4 & 4 & 3 & 4 & 4 & 3 & 4 & 3 & 2 & 4 & 3 & 4 & 4 & 3 & 3 & 4 & 4 & 3 & 4 & 3 & 70 & 0.090 \\
\hline e. Revenue Risk & 2 & 1 & 3 & 2 & 3 & 1 & 2 & 2 & 3 & 2 & 1 & 2 & 3 & 2 & 3 & 3 & 2 & 2 & 3 & 2 & 44 & 0.057 \\
\hline f. Construction Risks & 2 & 2 & 3 & 2 & 3 & 2 & 2 & 3 & 3 & 3 & 2 & 3 & 2 & 2 & 3 & 2 & 2 & 3 & 3 & 2 & 49 & 0.063 \\
\hline g. Land use & 4 & 2 & 3 & 4 & 2 & 2 & 3 & 3 & 3 & 3 & 2 & 2 & 4 & 3 & 3 & 2 & 3 & 2 & 2 & 3 & 55 & 0.071 \\
\hline h. Natural Risks & 2 & 2 & 2 & 4 & 2 & 3 & 2 & 3 & 2 & 2 & 3 & 3 & 3 & 2 & 3 & 3 & 3 & 2 & 3 & 3 & 52 & 0.067 \\
\hline i. Social Risk & 3 & 3 & 3 & 2 & 2 & 2 & 3 & 2 & 2 & 3 & 2 & 1 & 3 & 2 & 3 & 2 & 2 & 3 & 3 & 2 & 48 & 0.062 \\
\hline j. Design Risks & 3 & 2 & 2 & 4 & 2 & 1 & 2 & 4 & 1 & 3 & 1 & 1 & 2 & 4 & 2 & 2 & 4 & 2 & 3 & 2 & 47 & 0.061 \\
\hline k. Environment Risk & 2 & 2 & 2 & 2 & 3 & 3 & 2 & 2 & 1 & 2 & 1 & 1 & 3 & 2 & 3 & 2 & 2 & 2 & 2 & 2 & 41 & 0.052 \\
\hline 1. Logistic Risks & 2 & 2 & 3 & 2 & 3 & 2 & 1 & 4 & 2 & 2 & 2 & 2 & 2 & 3 & 1 & 3 & 3 & 1 & 1 & 2 & 43 & 0.055 \\
\hline m. Financial Risks & 3 & 2 & 2 & 1 & 2 & 2 & 2 & 2 & 2 & 3 & 2 & 1 & 2 & 3 & 3 & 3 & 3 & 2 & 3 & 2 & 45 & 0.058 \\
\hline n. Organizational Risks & 2 & 1 & 3 & 1 & 2 & 3 & 1 & 3 & 3 & 4 & 2 & 1 & 1 & 3 & 2 & 2 & 4 & 2 & 2 & 2 & 44 & 0.057 \\
\hline o. Operational Risks & 2 & 1 & 3 & 2 & 2 & 2 & 2 & 3 & 2 & 2 & 1 & 2 & 1 & 3 & 1 & 3 & 1 & 1 & 2 & 2 & 38 & 0.049 \\
\hline p. Health Risk & 2 & 1 & 2 & 1 & 3 & 1 & 2 & 3 & 1 & 2 & 2 & 2 & 2 & 2 & 2 & 2 & 1 & 2 & 2 & 2 & 37 & 0.048 \\
\hline
\end{tabular}


The developed risk assessment technique was applied to a real-time hydropower project namely Middle Modi Hydroelectric Project (15.1 MW), which is in construction phase on Modi River Basin in Parbhat in Western Region of Nepal. The project is a RoR type project.

Each parameter has a membership grading matrix. The membership grading matrices is developed considering the degree of error a scoring observer may cause due to subjectivity and bias in the assessment process. The following are the membership grading matrix used in this study.

\begin{tabular}{|c|c|c|c|c|c|c|c|c|c|c|c|c|c|c|c|c|c|c|c|}
\hline & 1 & 0.2 & 0 & 0 & & 1 & 0.2 & 0 & 0 & & 1 & 0.3 & 0 & 0 & & 1 & 0.2 & 0 & 0 \\
\hline \multirow[t]{4}{*}{$\mathbf{M 1}=$} & 0.2 & 1 & 0.2 & 0 & M5 $=$ & 0.2 & 1 & 0.2 & 0 & M9= & 0 & 1 & 0.3 & 0 & M13= & 0.2 & 1 & 0.2 & 0 \\
\hline & 0 & 0.2 & 1 & 0.2 & & 0 & 0.2 & 1 & 0.2 & & 0 & 0 & 1 & 0.3 & & 0 & 0.2 & 1 & 0.2 \\
\hline & 0 & 0 & 0.2 & 1 & & 0 & 0 & 0.2 & 1 & & 0 & 0 & 0.2 & 1 & & 0 & 0 & 0.2 & 1 \\
\hline & 1 & 0.3 & 0 & 0 & & 1 & 0.3 & 0 & 0 & & 1 & 0.3 & 0 & 0 & & 1 & 0.2 & 0 & 0 \\
\hline \multirow[t]{4}{*}{$\mathrm{M} 2=$} & 0 & 1 & 0.4 & 0 & M6= & 0 & 1 & 0.3 & 0 & M10 $=$ & 0 & 1 & 0.3 & 0 & M14= & 0.2 & 1 & 0.2 & 0 \\
\hline & 0 & 0 & 1 & 0.5 & & 0 & 0 & 1 & 0.3 & & 0 & 0 & 1 & 0.3 & & 0 & 0.2 & 1 & 0.2 \\
\hline & 0 & 0 & 0.2 & 1 & & 0 & 0 & 0.2 & 1 & & 0 & 0 & 0.2 & 1 & & 0 & 0 & 0.2 & \\
\hline & 1 & 0.3 & 0 & 0 & & 1 & 0.4 & 0 & 0 & & 1 & 0.2 & 0 & 0 & & 1 & 0 & 0 & 0 \\
\hline \multirow[t]{4}{*}{$\mathrm{M} 3=$} & 0 & 1 & 0.3 & 0 & M7 $=$ & 0 & 1 & 0.4 & 0 & M11= & 0.2 & 1 & 0.2 & 0 & M15= & 0.2 & 1 & 0 & 0 \\
\hline & 0 & 0 & 1 & 0.3 & & 0 & 0 & 1 & 0.4 & & 0 & 0.2 & 1 & 0.2 & & 0 & 0.4 & 1 & 0 \\
\hline & 0 & 0 & 0.2 & 1 & & 0 & 0 & 0.2 & 1 & & 0 & 0 & 0.2 & 1 & & 0 & 0.4 & 0.5 & \\
\hline & 1 & 0.5 & 0 & 0 & & 1 & 0.3 & 0 & 0 & & 1 & 0.2 & 0 & 0 & & 1 & 0 & 0 & \\
\hline \multirow[t]{3}{*}{ M4 $=$} & 0 & 1 & 0.5 & 0 & M8 $=$ & 0 & 1 & 0.3 & 0 & M12 $=$ & 0.2 & 1 & 0.2 & 0 & M16 $=$ & 0.2 & 1 & 0 & 0 \\
\hline & 0 & 0 & 1 & 0.5 & & 0 & 0 & 1 & 0.3 & & 0 & 0.2 & 1 & 0.2 & & 0 & 0.4 & 1 & \\
\hline & 0 & 0 & 0.2 & 1 & & 0 & 0 & 0.2 & 1 & & 0 & 0 & 0.2 & 1 & & 0 & 0.4 & 0.5 & \\
\hline
\end{tabular}




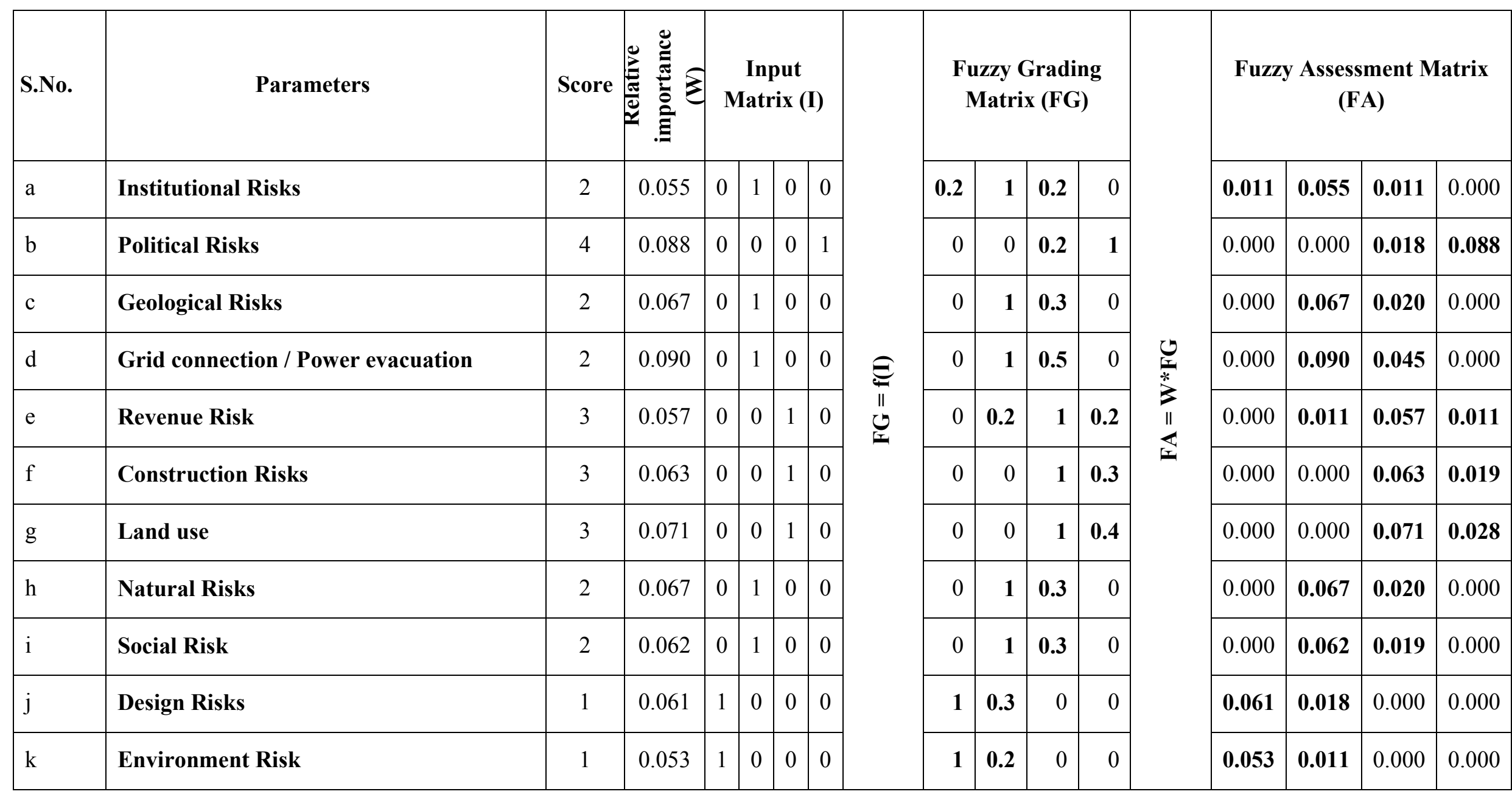




\begin{tabular}{|c|c|c|c|c|c|c|c|c|c|c|c|c|c|c|}
\hline 1 & Logistic Risks & 2 & 0.055 & 0 & 1 & \begin{tabular}{l|l}
0 & 0
\end{tabular} & 0.2 & 1 & 0.2 & 0 & 0.011 & 0.055 & 0.011 & 0.000 \\
\hline $\mathrm{m}$ & Financial Risks & 2 & 0.058 & 0 & 1 & \begin{tabular}{l|l}
0 & 0
\end{tabular} & 0.2 & 1 & 0.2 & 0 & 0.012 & 0.058 & 0.012 & 0.000 \\
\hline o & Operational Risks & 2 & 0.049 & 0 & 1 & \begin{tabular}{l|l}
0 & 0
\end{tabular} & 0.2 & 1 & 0 & 0 & 0.010 & 0.049 & 0.000 & 0.000 \\
\hline \multicolumn{11}{|c|}{ Membership Degree Matrix (MD) } & 0.205 & 0.555 & 0.403 & 0.158 \\
\hline \multirow{2}{*}{\multicolumn{11}{|c|}{ Decision Parameter (R) }} & A12 & A23 & A34 & AT \\
\hline & & & & & & & & & & & 0.38 & 0.48 & 0.28 & 1.14 \\
\hline
\end{tabular}

Table 3 Risk rating for Middle Modi Hydroelectric Project (15.1 MW), Parbat 
The membership degree curve for Middle Modi HEP skews moderately towards right and has got the risk rating of 1.91 which comes under MEDIUM RISK in our risk index.



Figure 1: Membership Degree Curve for Middle Modi Hydroelectric Project (15.1 MW), Parbat

\section{CONCLUSION}

- $\quad$ From the survey, among the type of risks, Grid Connection / Power Evacuation, Political risk and Geological risk were found to be predominant risk respectively in BOOT hydropower projects in Nepal.

- The applicability of the methodology was tested on a real case Middle Modi Hydroelectric Project (15.1 MW). Findings of the case study demonstrated that the proposed methodology can easily be applied by the professionals to quantify risk ratings. The advantage of the proposed methodology is that it will give investors a more rational basis to make decisions and it can prevent cost and schedule overruns. Forecasting the measure of risk of a river-type hydropower plant can be made by any decision maker with the help of the fuzzy rating tool.

- These risk items serve as a checklist that cover possible investment risks associated with BOOT Hydropower Project in pre-construction phase, construction phase and operational phase which are not addressed so far in case of Nepal. Risk managers or investment decision makers can be informed and be able to recognize the risks associated with BOOT Hydropower Project investments.

- An overall risk index can be used as early indicators of project problems or potential difficulties. Evaluators can keep track to evaluate the current risk level with the progress of investments.

\section{References}

1. Carr, J. H. M., Tah \& V. "A proposal for construction project risk." Construction Management and Economics (October 21, 2010): 491-500.

2. $\quad$ Edmundas K.Z, Zenonas T. \& Jolanta T. "Journal of Civil Engineering and Management." Risk Assessment of Construction Projects (2010): 33-46.

3. Patel G.P.,Singhal S. "Perception and Management of Risk in Hydropower Projects." International Conference on Hydropower for Sustainable Development (Feburary, 2015). 
4. Askari M, Shokrizade H.R.. "An integrated method for ranking of risk in BOT projects." ScienceDirect (2014).

5. Roy N.C., Roy N.G. , Pandey KK, Gupta S. "Risk Assessment and Distribution in Small Hydro Power Projects: A Fuzzy Approach." Twelfth AIMS International Conference on Management (n.d.).

6. Weimann P.,Muller G., Senior J. "Risk Management and Resolution Strategies for Established and Novel Technologies in the Low Head, Small Hydropower Market." University of Southampton, UK (n.d.).

7. $\quad$ Pokoradi, L. "AARMS." Fuzzy logic-based risk assessment" (March 18, 2002): 63-73.

8. Kucukali S. "Risk assessment of river-type hydropower plants by using fuzzy logic approach." World Renewable Energy Congress 2011- Sewden (May, 2011).

9. $\quad$ Shrestha R.S. "Hydropower Financing and Risk Mitigation." Bankers' Training, Pokhara (May 20 2010).

10. "Investment in Hydropower Sector: Opportunities and Risks." Nepal Hydro , Volume 1 , Issue 1 (June 5, 2007).

11. Ucar, B. "Coastal Scenic Evaluation by application of Fuzzy Logic Mathematics." Thesis (July, 2004): 1-139. 